\title{
THE DIGITAL DIVIDE IN MEXICO: A MIRROR OF POVERTY
}

\author{
Juan Manuel Mecinas MontieL*
}

\begin{abstract}
The Mexican digital divide is a problem of inequality that also reflects the poverty of certain cities/areas/groups in Mexico. This note analyzes the digital divide in Mexico, as well as the legal and constitutional efforts the Mexican government has made to breach it. In 2013 and 2014, the government approved an important constitutional amendment and other legal reforms in an attempt to solve this problem with a new fiber optic network and new institutional actors. By setting up a new infrastructure, private actors will be able to offer better broadband Internet services. Nevertheless, these efforts will not benefit those who are not Internet users: the have-nots.
\end{abstract}

KEY WORDS: Internet, digital divide, poverty, inequality, constitutional reforms, fiber optics, broadband connection.

Resumen. La brecha digital es un problema de desigualdad y que también refleja la pobreza de diversos(as) grupos/áreas/ciudades en el país. Este texto intenta analizar la brecha digital en México y los esfuerzos constitucionales y legales del gobierno mexicano para cerrarla. Durante 2013 y 2014, el gobierno aprobó distintas reformas constitucionales y legales que intentan resolver este problema con una nueva red fibra óptica y con nuevas instituciones. Se trata de una nueva infraestructura que permitirá a actores privados ofrecer mejores servicios de internet de banda ancha. Sin embargo, estos esfuerzos no beneficiarán a quienes no son usuarios de la red, los have-nots.

PALABRAS CLAVE: Internet, brecha digital, pobreza, desigualdad, reformas constitucionales, fibra óptica, conexión de banda ancha.

* Professor and Researcher at CIDE (Center for Economic Research and Teaching). Professor at Conacyt. He holds a PhD in Constitutional Law from the Complutense University and has done research at various universities and institutes such as the Max-Planck Institute (Heidelberg), Harvard University and Kassel University. Email:juan.mecinas@cide.edu. 
Esta revista forma parte del acervo de la Biblioteca Jurídica Virtual del Instituto de Investigaciones Jurídicas de la UNAM

TABLE OF CONTENTS

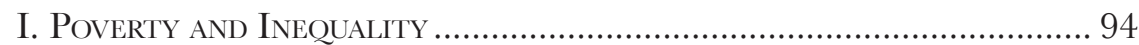

II. From Marcos's Myth to Peña Nieto's Reforms .............................. 95

III. Dominant Players and Infrastrugture.......................................... 97

IV. REFORMS AND POVERTY ................................................................... 99

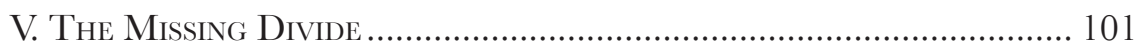

\section{Poverty and Inequality}

Maria and Francisca do not use a computer or a cell phone. Internet is a vague concept for them. With a kindhearted smile they claim that the Internet and computers are things for educated and wealthy people. They belong to a large number of Mexicans who do not use the Internet. Maria is a single mother of a two-year-old boy. She barely speaks Spanish and finds difficulties in selling handcrafted dresses in a small town in Chiapas - a state in southern Mexico in which one third of its inhabitants live in extreme poverty. $-{ }^{1}$ Francisca, her assistant, is younger (14) and only speaks Tzotzil. ${ }^{2}$

Different reasons explain the digital divide in Mexico, but it is essentially a consequence of poverty and inequality. Internet penetration in Mexico is similar to that of other countries in Latin America, with a low average of users in comparison with some European countries. ${ }^{3} 51.2$ million Mexicans have Internet access, ${ }^{4}$ which represents less than half of its population.

Internet access has a deeper penetration among wealthier Mexicans than the poorer sector of the population. 7 out of 10 members of the highest income bracket are Internet users, while this is the case of only 2 out of 10 members of the lowest income bracket, despite the fact that this last group represents about the same percentage of the Mexican population. ${ }^{5}$

1 CONEVAL, Indicadores de Pobreza, (2012), available at http://werere.coneval.gob.mx/coordinacion/entidades/Paginas/Chiapas/pobreza.aspx.

2 A language spoken by 291,550 citizens in Chiapas, most of them in the region called Altos de Chiapas. Comisión Nacional para el Desarrollo de los Pueblos Indígenas, Atlas de los Pueblos Indigenas de México, available at http://wwre.cdi.gob.mx/index.php?option=com_wrapperËview=wrap perङItemid $=200027$

3 For instance, in Belgium, Denmark and Norway, Internet access stands at around 85\%, $96 \%$ and $96.3 \%$, in that order, compared to Colombia, Mexico and Paraguay where these averages are 52.6\%, 44.4\% and 43\%, respectively. World Bank, World Development Indicators 2014, available at http://data.worldbank.org/indicator/IT.NET.USER.P2.

4 AMIPCI, Estudio sobre los hábitos de los usuarios de internet en México 2014, (2014), available at https://wrerreamipci.org.mx/estudios/habitos_de_internet/Estudio_Habitos_del_Internauta_Mexicano _2014_V_MD.pdf.

5 This figure stands at $23 \%$ and 26\%, respectively. Vid. AMIPCI, Estudio sobre hábitos de los usuarios de internet en México 2009. Available at https://werere.amipci.org.mx/estudios/habitos_de_internet/2010_Habitos_Usuarios_Internet_Mx.pdf. 
Esta revista forma parte del acervo de la Biblioteca Jurídica Virtual del Instituto de Investigaciones Jurídicas de la UNAM

A lack of academic education brings low income and fewer opportunities for Internet access. People who only received elementary education represent $21 \%$ of Internet users and they have four times fewer probabilities of using the Internet in Mexico. ${ }^{6}$

There is also a generational gap. People over 45 represent $12.3 \%$ of all Internet users ${ }^{7}$ even though they are $32.82 \%$ of the economically active population. ${ }^{8}$

Evidently, a lack of infrastructure is a key issue to understanding the situation. In 2012, just 26\% of Mexican households had Internet access and it varied among the States. For instance, in Sonora, Baja California, Nuevo León (border states with the U.S.) and in Mexico City (the capital), Internet accessibility was 4 out of every 10 households, while in poorer states like Oaxaca, Chiapas and Guerrero, the average was 1 out of every $10 .{ }^{9}$

This condition puts Mexico in the worst OECD rankings of Internet penetration and specifically in wireless broadband penetration. It also explains why Maria and Francisca, living in a poor state, having no formal schooling and with low incomes are far from living in a digital world.

\section{From Marcos’s Myth to Peña Nieto's Reforms}

In 2012 a movement called "\#YoSoy132” (“\#Iam132”) appeared in Mexican politics using the Internet. It was not the first case. In 1994 the EZLN had risen ${ }^{10}$ by using the Internet and changing the way of doing politics and igniting a revolution. The country and the world knew of the political claims of the EZLN through the web. ${ }^{11}$ The transmission of EZLN`s ideological platform was different due to the Internet ${ }^{12}$ and an indigenous agenda was put on the table.

6 INEGI, Módulo sobre Disponibilidady Uso de las Tecnologías de la Información en los Hogares 2014, (2015), available at http://wrewe3.inegi.org.mx/sistemas/microdatos/encuestas.aspx?c $=34519 \mathcal{E}^{2}=$ s $=$ st.

7 Idem.

8 INEGI, Encuesta Nacional de Ocupación y Empleo, Tercer Trimestre de 2014,(2015), available at http://wrerw.inegi.org.mx/lib/olap/consulta/general_ver4/MDXQueryDatos_Colores.asp?proy=enoe_ pe_pmay

9 Inegi, Estadísticas Sobre Disponibilidad y Uso de Tegnología de Información y Comunicaciones en Hogares 2013, 15 (2014).

10 The EZLN is an army with indigenous members denouncing political actions which emerged in Chiapas on January 1, 1994. See Carlos Tello. La Rebelión de las Gañadas (Cal y Arena, 1995).

11 Nevertheless, Marcos stated that it was a student in Texas who designed and controlled the web page and that he has never met this student. Vid, CNN México, El Subcomandante Marcos explica el uso de la tecnología del EZLN, available at http://mexico.cnn.com/nacional/2013/02/11/ el-subcomandante-marcos-explica-el-uso-de-la-tecnologia-del-ezln.

12 For instance, "Primera Declaración de la Selva Lacandona", available at http://palabra. ezln.org.mx/comunicados/1994/1993.htm 
But in 2012 the context had changed. "\#Yosoy 132" members were university students and the movement emerged during the presidential electoral campaigns. They asserted that Peña Nieto - the PRI candidate- was a liar ${ }^{13}$ and that he had built his position as the leader of the presidential race on a blurred relationship with the most important broadcaster in the country Televisa. ${ }^{14}$ If the EZLN showed the lack of an indigenous agenda, "\#YoSoy 132" showed the gap between old politics and new digital generations.

Nevertheless, Peña Nieto won the election. "\#YoSoy 132 " was a key factor in a very competitive election, but it faced structural limitations for such a movement: half of the Mexican population did not have Internet, which was its core means of communication. ${ }^{15}$

Although \#"YoSoy132" was about to make him lose the election, President Peña Nieto proposed an inclusive digital agenda. His decision is based on political and economic grounds. The ICT market means potential revenue of 60 billion USD a year in Mexico; however, it required a new framework. Mexican politics was full of continuous and useless political efforts trying to breach the digital divide and offering incentives for a competitive market. In 2013, Mexico began to amend its constitutional and legal frameworks on ICT. It was a turning point in political and legal terms. The leitmotiv of the amendments was not essentially breaching the digital divide, but opening the telecommunications market (controlled by America Movil - a Carlos Slim company - in the phone and mobile phone sector and Televisa in television and broadcasting).

The dispute between Televisa and America Movil also explains the reforms and the fight for control over the telecommunications market. The Mexican ICT sector was living under a laissez-faire policy with a lack of governmental infrastructure and two dominant actors leading the business. Obviously, the reform is in part the State's late reaction to this challenge that stresses the need for a national agenda for digital inclusion.

Competitiveness was the goal because two dominant players were not enough for such a broad market. Having more public TV channels and a better ICT infrastructure are fundamental tools for governments in modern democracies. The Mexican government aims to have real control with a reform that underlines three legal features:

13 During his visit to the Ibero-American University campus, Peña Nieto dismissed a protest claiming that there were only 131 demonstrators. The movement started on social networks on the premise that they were students and the name \#Yosoyl32 meant everybody who joined the dismissed group.

14 Other media had already denounced this connection. See Jenaro Villamil, Televisay la imposición de Peña Nieto, Proceso, July 2, 2012, available at http://wrerw.proceso.com.mx/?p=312908.

15 University students were $5 \%$ of the electorate. A majority of people with less formal education voted for Peña Nieto. See Consulta Mitofksky, México 1o. de Julio de 2012. Perfil del Votante, available at http://consulta.mx/web/images/elecciones/2013/20120701_Perfil_Votante.pdf. 
a. ICT access as a fundamental right. The constitution recognizes Internet access as a fundamental right.

b. The creation of an independent institute that will focus on ICT licenses and concessions.

c. Discussion of two scenarios: ICT infrastructure - the creation of a "shared network" - and television broadcast.

The transitional articles of the amendment expressed the government's target to attain universal digital access. By the end of 2018, the Mexican government aims to extend Internet access to reach $70 \%$ of Mexican households and for $85 \%$ of micro, small and medium-sized companies to have Internet access with "real speed to download information".

\section{Dominant Players and Infrastructure}

Besides poverty and inequality, a two-head monster challenges the efforts to breach the Mexican digital divide. One head is the Dominant Players - actually a sort of group of monopolies - and the other is a lack of infrastructure to provide more and better services in the telecommunications sector.

Regarding the players, in recent months the $\mathrm{IFT}^{16}$ declared America Movil and Televisa as the Dominant Players in the telecommunications sector in Mexico. America Movil

- through Telcel and Telmex - accounts for $70 \%$ of the mobile market and around $70 \%$ of the fixed market. On the other hand, with a market share of $67 \%$, Televisa dominates television and broadcasting service. ${ }^{17}$ This declaration is a result of the new constitutional and legal framework in order to compel them to share their infrastructure with other competitors. ${ }^{18}$

Concerning the infrastructure, Mexico has the worst OECD ranking in wireless broadband penetration. While in most OECD countries there are almost 3 wireless broadband subscriptions for every 4 inhabitants, in Mexico the percentage is about $14 \%$ - almost 1 subscription for every 7 inhabitants. ${ }^{19}$ There is a lack of fiber optic infrastructure to transmit data and offer cheaper services with better quality.

Under this scenario, the constitutional amendments and a law reform on telecommunications - approved between June 2013 and July 2014 - stressed the Mexican government's interest in having a better fiber optic infrastructure

16 This is the top official Mexican regulator on ICT since 2013.

17 PriceWaterhouse Coopers, Nordic Investment in Mexico. Telecommunication services, available at http://wrerc.pwc.com/es_MX/mx/international-business-center/archivo/2014-11-telecommunications.pdf.

18 Nevertheless, in a much criticized ruling last October, the IFT found that Televisa is not dominant in cable and satellite television markets, which will let the company continue increasing its market share.

19 OECD, Broadband statistics, available at oecd.org/sti/ict/broadband 
and more competitors, and articulated its concerns as to who can use the Dominant Players' infrastructure. The aim of these reforms was to kill the monster: building up the digital infrastructure ${ }^{20}$ and creating incentives for real competition in the telecommunications sector.

Currently the Mexican government holds a "core network" of fiber optic of about 25,500 kilometers. By the end of 2018, it aims to own 82,500 kilometers. ${ }^{21}$ Unfortunately this is not the largest fiber optic network in the country. America Movil owns more than 167,000 kilometers of fiber optics (twice the amount the government aims to have by the end of 2018). ${ }^{22}$

The infrastructure exists even though it belongs to a private company. The government decided to build a new one to control the market and guarantee net neutrality. In this sense the decision seems quite rational because new actors will not depend on America Movil so as to enter into the market. They will need to invest in the "last mile" and not in the "middle mile". However, new actors cannot be obliged to invest in non-profitable markets. In this sense, the relationship between poverty, exclusion and services becomes significant: new actors will not be attracted to markets with high rates of poverty.

Having a larger fiber optic network does not immediately result in a deeper penetration of Internet. Even though America Movil owns a large fiber optic network, it cannot offer a broadband connection to everyone. In other words, an automatic consequence of the efforts to build a larger fiber optic network is not necessarily a decrease in the digital divide. The government knew it and decided to create a network that can reach $70 \%$ of the Mexicans households and can connect $80 \%$ of the small and medium companies.

Having more service providers with better and cheaper products offered through a government network will be very attractive for customers who can pay for those services, but not for those who cannot. The good news is that it will benefit most of the Mexicans who are already connected. Government efforts will bring new competitors, ${ }^{23}$ but that bad news is that it will not necessarily bring more cybercitizens.

For instance, new companies/alliances created to offer services - with the benefits of the shared network built by the government - concentrate their business in cities with large concentrations of Internet users. ${ }^{24}$

\footnotetext{
20 According to the government, this new "shared network" will cover $98 \%$ of the Mexican population.

21 In this sense there is a double risk: time and technology. As long the government does not reach its goal, it will be inadequate to provide coverage for forthcoming technological developments.

22 An obvious question arises: Why did the government decide not to use America Movil's larger fiber optic network while building its own "shared network"?

23 For instance, in recent months AT\&T bought Iusacell — an important company in the mobile sector - and Nextel de México and will challenge the dominance of America Movil and Televisa.

24 This is the case of "Izzi" — a new Internet service provider-. Vid. Luis González and Nicolás Lucas, Izzi propone más que una Guerra de tarifas: Televisa, El Economista, Nov. 4,
} 
Therefore, in order to breach the digital divide, it is not sure whether the creation of the network was a reasonable solution in the short and long run. In the meantime it is not clear whether the government will invest in the "last mile" and under what conditions. Furthermore, it is not only a matter of fiber optics, but of towns/cities where the new "shared network" will run.

Experiences show that markets do not close gaps. Fiber optics and broadband connections depend on the attractiveness of the market based on the size of the population, the terrain, the economic situation and the amount of the investment. ${ }^{25}$

The State should undoubtedly have some sort of control over the telecommunications sector. ${ }^{26}$ However, it is just part of the solution. Closing the digital divide depends on whether the government wants to invest in places where the market does not.

This is a huge risk because a deeper gap can arise between those who are already connected and those who are not. Digital divide is not only a matter of access but of the quality of access and skills. So, by the end of 2018, 70\% of Mexican households will have Internet. The problem will remain for the remaining $30 \%$. If they are the same households that do not have Internet today, we face a problem, the solution to which is not found in the reforms or current policies. The Mexican reforms were a good idea for the existing customers, but it is a risky gamble for citizens with no Internet access. In 2018, the gap may become even deeper.

\section{REForms AND Poverty}

Some facts cast doubt on the success of the government's ambitions for different reasons:

1. In households with a computer, the lack of Internet access is due to economic reasons. ${ }^{27}$ Therefore, the problem is not only one of infrastructure. In the end, it lies in the possibility of paying for the services offered on the market.

2. In Mexico, people with lower income spend less money on transportation and communications. A service provider will not invest in neigh-

\footnotetext{
2014, available at http://eleconomista.com.mx/industrias/2014/11/04/izzi-telecom-propone-masque-guerra-tarifas-televisa

25 This also happens in other countries. Vid. Susan P. Crawford and Robyn Mohr, Bringing Municipal High-Speed Internet Access to Leverett, Massachusetts, December 17, Berkman CEnTER Research Publication 26, 12, (2013), available at SSRN: http://ssrn.com/abstract=2366044.

${ }^{26}$ Julia Neumann, Bridging the Digital Divide, 49-50, 102 (Carl Heymanns Verlag 2012)

27 This was the main reason in $62 \%$ of the cases. See INEGI, Estadísticas Sobre Disponibilidad y Uso de Tecnología de Información y Comunicaciones en Hogares, 201316 (INEGI 2014).
} 
borhoods/towns where people cannot afford Internet services due to their economic situation. ${ }^{28}$

3. The latest official data showed that one third of Mexican households do not have a cell phone ${ }^{29}$ and $38 \%$ of the population does not use a cell phone at all. ${ }^{30}$ This is a big contradiction because there are more than 100 million cell phone subscriptions. ${ }^{31}$ In states like Oaxaca, $60 \%$ of the households have no cell phone in contrast with Baja California Sur where the figure stands at $87 \%$. Data shows that even when there is infrastructure to use a cell phone, (with or without a data plan to access the Internet) one third of the households do not have it, especially in the poorest states. ${ }^{32}$

4. The lack of Internet access in households is severe and the government's aim to reach $70 \%$ of them seems far away (today it is around $26 \%$ ). Most states in Mexico did have statistics showing $80 \%$ of their households without Internet access, with cases like Chiapas where the average is $92 \%{ }^{33}$

5. Reality does not show a real possibility of bridging the digital gap in the next decade under the policies implemented by the Mexican government. $11.3 \%$ of Mexican households have no potable water. Almost half of the households in towns with fewer than 2,500 inhabitants use firewood and coal to cook. These indicators make difficult to believe that the Mexican situation in terms of the digital divide can change in view of such disparities and contradictions in basic services.

6. Data show a country that needs to fill in other gaps in order to fill the digital one. Internet access is very important for Mexican economy, but water, electricity and other basic services are more important. There is a lack of such infrastructure in a large number of Mexican households.

28 In the poorest decile, households spend more than $50 \%$ to buy food and just $9.8 \%$ on Transportation and Communication. On the other side, one-fifth decile of the population spends $16.7 \%$ of their income on Transportation and Communication and the richest one, $19.7 \%$.

29 INEGI. Módulo sobre disponibilidad y uso de las tecnologías de la información, 2014, available at http://wrere3.inegi.org.mx/sistemas/microdatos/encuestas.aspx?c=34519\&s=est.

30 INEGI, Estadísticas Sobre Disponibilidad y Uso de Tecnología de Información y Comunicaciones en Hogares, 2013, supra note 9, at 20.

31 IFETEL, Sistema de información estadística de mercados de telecomunicaciones, available at http:// siemt.cft.gob.mx/SIEM/

32 These include the states of Chiapas, Guerrero (56\%) and Puebla (50\%). INEGI, Censo de Población y Vivienda 2010, available at http://wwersinegi.org.mx/sistemas/olap/Proyectos/bd/censos/ cpv2010/Viviendas.asp? $=e s t \mathcal{E}^{2}=27875 \mathcal{E}^{2}$ proy $=c p v 10 \_$viviendas.

33 Ibidem. 
In other words, the infrastructure that the government will control in the short run is necessary, but it is not really a solution at all. The highest concentration of this lack of Internet access in households occurs in the poorest states, which is indicative of a much more serious problem: poverty.

\section{The MISSING DIVIDE}

Maria and Francisca were partially right. In their town (and in other places in Mexico), Internet access and digital skills are not for everyone, regardless of whether the constitution declares it as fundamental right. The law is far from being a certainty in this country.

Even if the government is able to connect today's have-nots, it will not close the digital divide because its programs are not accompanied with an ambitious digital skills policy. The first definitions of digital divide considered it an infrastructure and physical problem. ${ }^{34}$ Nevertheless, experience shows that infrastructure and gadgets are not enough to breach the digital gap. ${ }^{35} \mathrm{In}$ other words, the gap is not only about hardware and software..$^{36}$ Approaching the digital divide as a hardware and software problem widens the gap between Internet users and those who do not access to the web. It would be like having cars and highways and still be unable to drive because the potential driver does not know how to.

The divide may be economic and physical, but it is also a gap in terms of skills. ${ }^{37}$ The simplification of the issue from an infrastructure or an economical perspective faces only deals with one part of the problem. Reality shows it to be a problem with several ramifications. Having infrastructure and gadgets is essential to close the gap, but digital skills are a pending task for the Mexican government, which normally does not pay attention to this aspect. The digital divide is a moving target due to the continuous changes in technologies and gadgets. Infrastructure is useless if it is not accompanied by programs focused on skills. If we want the Internet to become a real and powerful tool in economic and political terms, hardware, software and skills are a necessary trilogy. The government is not running a national digital skills program. ${ }^{38}$

34 Appu Kuttan and Laurence Peters, From Digital Divide to Digital Opportunity 4 (Scarecrow Press, 2003).

35 Pippa Norris, Digital Divide: Civit Engagement, Information Poverty, and the InTERNET WorLdWIDE 16 (Cambridge University Press, 2001).

36 Mark Warschauer, Technology and Social Inclusion. Rethinking the Digital DiVIDE 1-5(MIT Press, 2004); Jan Van Dijk, The digital divide as a complex and dynamic phenomenon, Spring, The Information Society (2002), at 1-2.

37 Lisa Servon, Bridging the Digital Divide. Technology, Community, and Public PoLICy 6 (Blackwell Publishers 2002).

38 There is a "Pilot Program for Digital Inclusion" in place. It does not focus exclusively on digital skills, but mainly on providing gadgets to Mexican students. See http://wrerrepresidencia. gob.mx/edn/desarrollo-de-habilidades-digitales-en-el-programa-piloto-de-inclusion-digital. 
Esta revista forma parte del acervo de la Biblioteca Jurídica Virtual del Instituto de Investigaciones Jurídicas de la UNAM

There are efforts to provide gadgets; however they are like giving an aspirin to cure a serious disease.

In some sense, people like Maria and Francisca will continue to struggle to pay their bills because they live away from the digital world. Mexico is far from breaching the digital divide. The government has done part of its job, but it will not be enough to narrow the gap. 